\title{
mRNA expression of CYP17A1, CYP11A1, CYP19A1, HSD3B1 and AKR1C2 in metastatic and non-metastatic prostate cancer patients
}

Indrawarman Soerohardjo*, Muhammad Puteh Mauny, Alharsya Franklyn Ruckle, Ahmad Zulfan Hendri, Didik Setyo Heriyanto, Raden Danarto

Urology Division, Department of Surgery, Faculty of Medicine, Public Health and Nursing, Universitas Gadjah Mada/Dr. Sardjito General Hospital, Yogyakarta, Indonesia

DOI: http://dx.doi.org/10.19106/JMedScie/005004201808

\section{ABSTRACT}

The progression of prostate cancer ( $\mathrm{PCa}$ ) mainly occurs caused by androgens. There is a link between intratumoral steroidogenesis and castration-resistant prostate cancer. This study aimed to determine the mRNA expression of various steroidogenic enzymes (CYP17A1, CYP11A1, CYP19A1, HSD3B1, and AKR1C2) in metastatic and non-metastatic prostate cancer patients. This study was conducted at the Anatomical Pathology Laboratory and Urologi Division, Department of Surgery, Faculty of Medicine, Public Health and Nursing, Universitas Gadjah Mada/Dr. Sardjito General Hospital, Yogyakarta from SeptemberNovember 2017. Samples were taken from 30 paraffin blocks with adenocarcinoma of prostate, stained with hematoxylin-eosin (HE) and then classified into metastatic and nonmetastatic groups. Samples then underwent deparaffinization procedure and examination of mRNA expression of CYP17A1, CYP11A1, CYP19A1, HSD3B1, AKR1C2 genes using Real-Time PCR. The mean mRNA expressions of CYP11A1, CYP17A1, CYP19A1, $H S D 3 B 1$, and $A K R 1 C 2$ genes in the metastatic adenocarcinoma prostate group were 7.08, $10.11,3.94,4.84$ and 3.58 , respectively. In the non-metastatic group, the mean mRNA expressions of CYP11A1, CYP17A1, CYP19A1, HSD3B1, and AKR1C2 genes were 4.62, $9.45,3.46,2.68$ and 4.92 , respectively. The mean of mRNA expression of CYP11A1, CYP17A1, CYP19A1, and HSD3B1 genes were higher in the metastatic group than nonmetastatic adenocarcinoma prostate group. However, it was not statistically significant $(p>0.05)$. The highest mRNA expression of steroidogenic enzymes was the CYP17A1 gene. In conclusion, the mRNA expressions of CYP17A1, CYP11A1, CYP19A1, HSD3B1 were higher in the metastatic prostate cancer patients compared to that in non-metastatic prostate cancer patients but statistically not significant.

\section{ABSTRAK}

Perkembangan kanker prostat (PCa) terutama terjadi karena androgen. Ada hubungan antara steroidogenesis intratumoral dan kanker prostat yang resisten-kastrasi. Penelitian ini bertujuan untuk mengkaji ekspresi mRNA dari berbagai enzim steroidogenik (CYP17A1, CYP11A1, CYP19A1, HSD3B1, dan AKR1C2) pada kanker prostat metastatik dan nonmetastatik. Penelitian ini dilakukan di Laboratorium Patologi Anatomi dan Divisi Urologi, Departemen Bedah, Fakultas Kedokteran, Kesehatan Masyarakat dan Keperawatan, Universitas Gadjah Mada/Rumah Sakit Umum Pusat Dr. Sardjito dari September-November 2017. Sampel diambil dari 30 blok parafin dengan adenokarsinoma prostat dan diwarnai dengan pewarna hematoxylin-eosin (HE) untuk selanjutnya dikelompokkan menjadi kelompok metastasis dan non-metastasis. Sampel selanjutnya dideparafinisasi dan diukur ekspresi mRNAnya untuk gen-gen CYP17A1, CYP11A1, CYP19A1, HSD3B1, AKR1C2 menggunakan Real-Time PCR. Ekspresi mRNA rata-rata untuk gen CYP11A1, CYP17A1, CYP19A1, HSD3B1, dan AKR1C2 pada kelompok prostat metastasis adenokarsinoma berturut-turut adalah 7,08, 10,11, 3,94, 4,84 dan 3,58. Pada kelompok non-metastatik, ekspresi mRNA rata-rata untuk gen-gen CYP11A1, CYP17A1, CYP19A1, HSD3B1, dan $A K R 1 C 2$ berturut-turut adalah 4,62, 9,45, 3,46, 2.68 dan 4,92. Rata-rata ekspresi mRNA 
gen CYP11A1, CYP17A1, CYP19A1, dan HSD3B1 lebih tinggi pada kelompok pasien prostat adenokarsinoma metastasis dibandingkan kelompok non-metastatik, tetapi secara statistik tidak signifikan $(p>0,05)$. Ekspresi mRNA tertinggi dari enzim steroidogenik adalah gen CYP17A1. Dapat disimpulkan, ekspresi mRNA dari CYP17A1, CYP11A1, CYP19A1, $H S D 3 B 1$ lebih tinggi pada pasien kanker prostat metastatik dibandingkan non-metastatik tetapi secara statistik tidak signifikan.

Keywords: Prostate cancer - CYP17A1 - metastatic - non-metastatic - steroidogenesis, mRNA

\section{INTRODUCTION}

Prostate cancer $(\mathrm{PCa})$ is the $4^{\text {th }}$ most common type of malignancy in men worldwide after skin, lung and colon cancers. According to GLOBOCAN data in 2008 , prostate cancer ranked $5^{\text {th }}$ in Indonesia. Based on data from the Indonesian Society of Urologic Oncology in 2011, there were 971 people with prostate cancer in the period 2006-2010 with the level of stage 4. Data obtained from Dr. Cipto Mangunkusumo General Hospital, Jakarta and Dharmais Cancer Hospital, Jakarta showed an increase in the number of patients with prostate cancer, with the number of patients per year around 70-80 new cases per year. ${ }^{1}$ As the second-leading cause of cancer-related deaths, prostate adenocarcinoma is the most commonly diagnosed non-cutaneous malignancy in men. Although early screening and detection has good prognosis, a significant number of men seek treatment with advanced or metastatic disease. ${ }^{2}$

The pathway of androgen hormone activation has an important role in the development and progression of prostate cancer (FIGURE 1). ${ }^{3}$ Studies show the presence of intratumoral androgen biosynthesis remains active with increased activity of steroidogenesis enzymes in castrated tumors of the prostate. One of the factors that cause the increase in the activity of intratumoral androgen metabolism is epigenetic changes. In these cases, the process of methylation and change of the

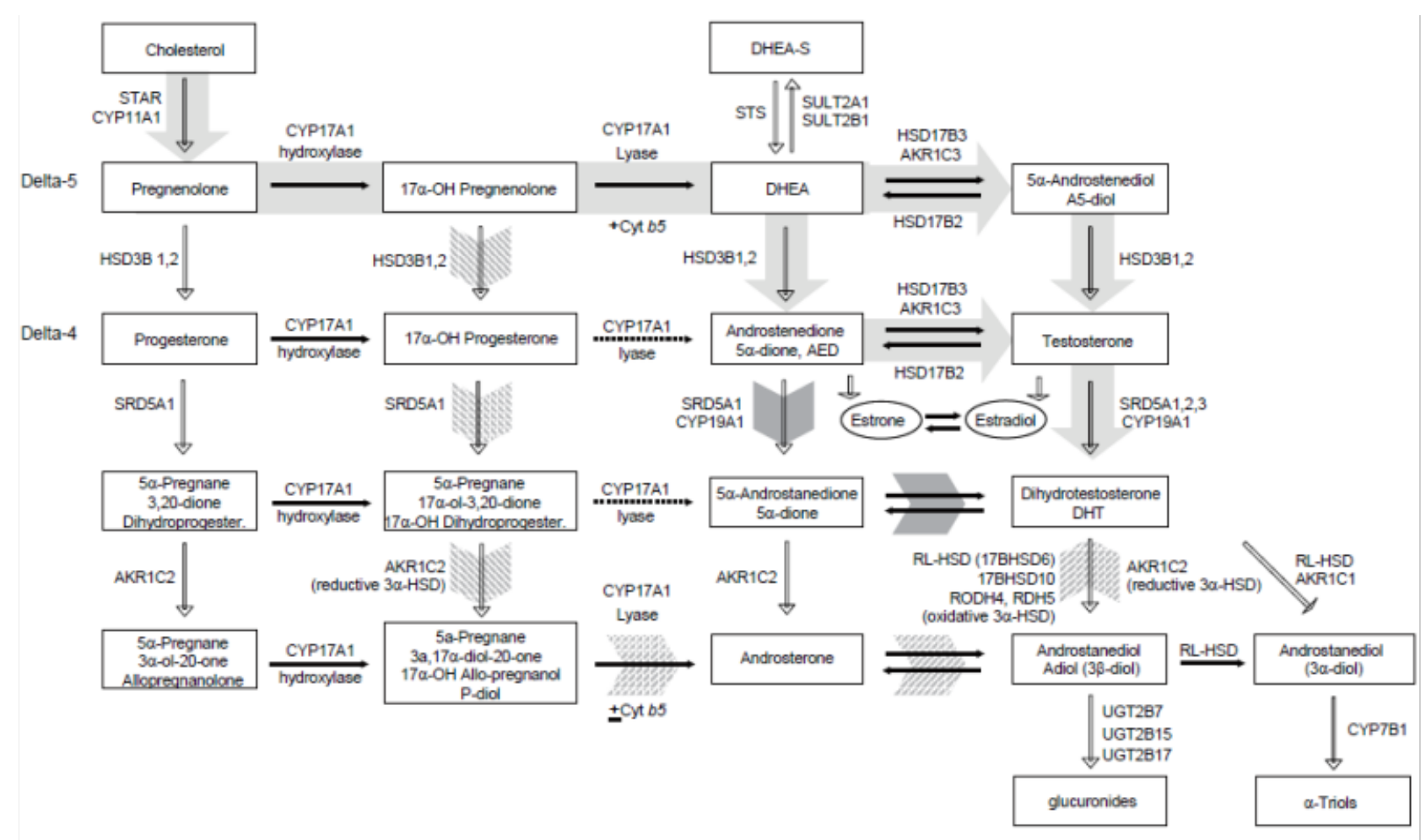

FIGURE 1. Androgen metabolic pathway ${ }^{4}$ 
DNA structure in prostate cancer cells occur significantly in a number of newly identified steroidogenic enzyme regulatory genes: CYP17A1, CYP11A1, CYP19A1, HSD3B1, $A K R 1 C 2{ }^{4}$

Current strategy in management of prostate cancer mainly involves using hormonal suppression therapy; however, major groups of patients develop castrationresistant prostate cancer (CRPC). A few predictive markers of response to hormonal manipulation have been developed, but due to variation in inter-racial epigenetics, further understanding of epigenetics is needed to develop deliberate therapy on PCa. In this study, we examined each cascade of steroidogenesis in prostate cancer to evaluate our strategy in Indonesia on management of these cases.

\section{MATERIALS AND METHODS}

\section{Patients}

This study was conducted at Urology Division, Department of Surgery, Dr. Sardjito General Hospital, Yogyakarta, Indonesia from September-November 2017. The study was approved by the Medical and Health Research Ethics Committee of Faculty of Medicine, Public Health and Nursing, Universitas Gadjah Mada/ Dr. Sardjito General Hospital, Yogyakarta. Samples were taken from 30 paraffin blocks with adenocarcinoma of prostate. The samples were cut and the slices were placed into object glass slides and stained with hematoxylin-eosin (HE). After microscopic reexamination of the samples, we divided the samples into two groups: non-metastatic and metastatic group. Later the samples underwent deparaffinization procedure, and the mRNA expression of CYP17A1, CYP11A1, CYP19A1, HSD3B1, AKR1C2 genes from all of the samples were measured using Real-Time PCR.

\section{Real-Time PCR}

The study lasted for three months in the Anatomical Pathology Laboratory, Faculty of Medicine, Public Health and Nursing, Universitas Gadjah Mada, Yogyakarta. The course of study was as follows: PCa sample was extracted with Total RNA Kit GeneAll ${ }^{\circledR}$. Real-Time PCR stage was processed using KAPA SYBR ${ }^{\circledR}$ fast qPCR Kit. Mapping of the samples was programmed within the PCR including the negative control. Mixtures of solution were made with composition as follows: $6.4 \mu \mathrm{L}$ PCR-grade water, 10 $\mu \mathrm{L}$ KAPA SYBR ${ }^{\circledR}, 0.4 \mu \mathrm{L}$ forward primer (CYP17A1/CYP11A1/CYP19A1/HSD3B1/ $A K R 1 C 2), 0.4 \mu \mathrm{L}$ reverse primer (CYP17A1/ CYP11A1/CYP19A1/HSD3B1/AKR1C2), $0.4 \mu \mathrm{L}$ deoxyuridine triphosphate (dUTP), $0.4 \mu \mathrm{L}$ KAPA RT MIX, $2 \mu \mathrm{L}$ RNA template (TABLE 1). The mixtures were placed into 48 well plates for every primer. Step of PCR and condition of DT lite real-time PCR system were presented in TABLE 2.

TABLE 1. Sequence of the gene primer

\begin{tabular}{lll}
\hline Primer & \multicolumn{1}{c}{ Forward sequence } & \multicolumn{1}{c}{ Reverse sequence } \\
\hline GADPH & GCATCCTGG GCTACACTGAG & TCCACCACCCTGTTGCTGTA \\
CYP19A1 & CTGCAGACACTACTACTACA & ATCCGAGTCACTGCTCTCAG \\
CYP11A1 & AGACACTGAGACTCCACCCCA & GACGGCCACTTGTACCAATGT \\
CYP17A1 & AGCTCGTGGCTCTCTTGCTG & CGCGATGTCTAGAGTTGCCA \\
HSD3B1 & TTCCGCCCTCTCTGAGGTACT & GGTCACGAAGTGGCGATTG \\
AKR1C2 & GTAAAGCTCTAGAGGCCGT & CACCCATGGTTCTTCTCGA \\
\hline
\end{tabular}


TABLE 2. Step of PCR, condition of DT lite real-time PCR system (DNATechnology)

\begin{tabular}{lccc}
\hline Step of PCR & Temperature & Duration & Cycle \\
\hline Reverse transcription & $42{ }^{\circ} \mathrm{C}$ & $5 \mathrm{~min}$ & - \\
Enzyme activation & $95{ }^{\circ} \mathrm{C}$ & $3 \mathrm{~min}$ & - \\
Denaturation & $95{ }^{\circ} \mathrm{C}$ & $1-3 \mathrm{sec}$ & 40 \\
Extension & $60{ }^{\circ} \mathrm{C}$ & $\geq 20 \mathrm{sec}$ & 40 \\
\hline
\end{tabular}

\section{RESULTS}

The mean mRNA expressions of $C Y$ P11A1, CYP17A1, CYP19A1, HSD3B1, and $A K R 1 C 2$ genes in the metastatic PCa group were $7.08,10.11,3.94,4.84$ and 3.58, respectively. In the non-metastatic PCa group, the mean mRNA expressions of $C Y P 11 A 1, C Y$ P17A1, CYP19A1, HSD3B1, and AKR1C2 genes were 4.62, 9.45, 3.46, 2.68 and 4.92, respectively (TABLE 3 ). The mean mRNA expressions of the CYP17A1 gene were the highest expression found in both non-metastatic and metastatic PCa groups.

TABLE 3. mRNA expression of CYP11A1, CYP17A1, CYP19A1, HSD3B1, and $\mathrm{AKR} 1 \mathrm{C} 2$ genes

\begin{tabular}{clcl}
\hline Genes & \multicolumn{1}{c}{ PCa } & $\mathrm{n}$ & \multicolumn{1}{c}{ Mean } \\
\hline \multirow{2}{*}{ CYP11A1 } & Metastatic & 16 & 7.0813 \\
& Non-Metastatic & 14 & 4.6250 \\
CYP17A1 & Metastatic & 16 & 10.1113 \\
& Non-Metastatic & 14 & 9.4536 \\
& Metastatic & 16 & 3.9425 \\
CYP19A1 & Non-Metastatic & 14 & 3.4643 \\
& Metastatic & 16 & 4.8469 \\
AKR1C2 & Metastatic & 16 & 3.5800 \\
& Non-Metastatic & 14 & 4.9221 \\
\hline
\end{tabular}

There were no significant differences between the mean mRNA expressions of CYP11A1, CYP17A1, CYP19A1, HSD3B1, and $A K R 1 C 2$ genes in the non-metastatic PCa groups compared to the metastatic $\mathrm{PCa}$ groups. This result of groups mean is showed in TABLE 4.
TABLE 4. Mean comparison between groups

\begin{tabular}{lcc}
\hline Genes & $\mathrm{p}$ & Mean \pm SEM $^{*}$ \\
\hline CYP11A1 & 0.206 & $2.45 \pm 1.89$ \\
CYP17A1 & 0.772 & $0.66 \pm 2.25$ \\
CYP19A1 & 0.740 & $0.48 \pm 1.42$ \\
HSD3B1 & 0.095 & $2.16 \pm 1.25$ \\
AKR1C2 & 0.474 & $-1.34 \pm 1.85$ \\
\hline *SEM: standard error of the mean
\end{tabular}

\section{DISCUSSION}

Steroidogenesis requires specific hormones and can occur throughout the body. These steroid hormones depend on cholesterol, which is present in all tissues and is necessary for steroid biosynthesis. ${ }^{5}$ Steroidogenic acute regulatory protein (STAR) transports cholesterol into the mitochondria in order to convert it to pregnenolone by cholesterol side-chain cleavage enzyme P450scc (CYP11A1). ${ }^{6}$ This CYP11A1 activity is essential for steroidogenesis. During this process, pregnenolone is converted either by $3 \beta$-hydroxysteroid dehydrogenase (HSD3B) to progesterone or by $17 \alpha$-hydroxylase (CYP17A1) to $17 \alpha-\mathrm{OH}-$ pregnenolone. ${ }^{7}$ In this study, both non-metastatic and metastatic groups showed expression of CYP11A1, the mean expressions are 4.62 and 7.08 , respectively. The mean expressions of CYP17A1 in non-metastatic and metastatic group are 9.45 and 10.1 , respectively.

One important regulator of the balance between androgens and estrogens is aromatase enzyme, encoded by CYP19A1 gene (15q21.1), which is involved in circulating and tissue levels of these hormones in the prostate. Aromatase inhibitors have been found to block the production of estradiol and effective in breast cancer treatment. They pose another possibility for prostate cancer treatment, demonstrating that intraprostatic estradiol may be involved in the disease progression. ${ }^{8}$ In this study, both non-metastatic and metastatic groups showed expression of 
CYP19A1, and the mean expressions were 3.46 and 3.94, respectively.

The $H S D 3 B$ gene family consists of two genes and five pseudogenes, located in chromosome band 1p13.1. The enzyme 3b-hydroxysteroid dehydrogenase (HSD3B) deactivates dihydrotestosterone (DHT). The type I and type II enzymes are differentially expressed. ${ }^{4}$ It was reported that $H S D 3 B$ expression increase in castrationresistant prostate cancer (CRPC), causing increased androstenedione levels, which could generate testosterone. ${ }^{9}$ In this study, both non-metastatic and metastatic groups showed expression of HSD3BI with the mean expressions were 2.68 and 4.84, respectively. In the previous study, variant allele of $H S D 3 B 1$ in Chinese population has been reported by $\mathrm{Wu}$ et. al. ${ }^{10}$ In this population patients who have a variant of $H S D B 3 B 1$ gene are more likely to progress to CRPC. This gene might also has a role in the prostate cancer progression in Indonesian population.

$A K R 1 C 2$ is a member of the newly emerging Aldo-Keto reductase (AKR) gene family, which metabolize selected steroid hormones, such as progesterone, DHT and androstenedione as well as polyaromatic hydrocarbons. While sharing many similar characteristics such as genomic structure, amino acid and nucleotide sequences, these specific genes catalyze the reduction of selective steroids and are expressed in a variety of human tissues. ${ }^{11}$ In this study, both non-metastatic and metastatic groups showed expression of $A K R 1 C 2$, and the mean expression was 4.92 and 3.58, respectively.

\section{CONCLUSION}

In this study, the mRNA expression of steroidogenic enzyme genes was not significantly increased in metastatic compared to the non-metastatic PCa groups. These results suggest that the presence or increased expression of steroidogenic enzyme genesare not clearly associated with metastatic PCa. Steroidogenic enzyme genes can also be seen in prostate cancer not merely in castration-resistant prostate cancer.

The highest mean mRNA expression of steroidogenic enzyme genes was the CYP17A1 gene, the mean mRNA expression were high both in non-metastatic and metastatic $\mathrm{PCa}$ groups. CYP17A1 gene could be a prognostic factor for prostate cancer in progression to castration-resistant prostate cancer. Further research on protein level with a multicenter study and a larger number of samples are necessary to clarify these results.

\section{ACKNOWLEDGEMENTS}

We would like to thank the patients and their families who have contributed to these studies. We also thank all those who provided excellent technical support and assistance during the study.

\section{REFERENCES}

1. Umbas R, Hardjowijoto S, Safriadi F, Mochtar C, Djatisoesanto W, Soedarso M. Panduan penata laksanaan kanker prostat 2011. Jakarta: IAUI; 2011.

2. Chandrasekar T, Yang JC, Gao AC, Evans CP. Targeting molecular resistance in castration-resistant prostate cancer. BMC Med 2015;13:206. https://doi.org/10.1186/s12916-015-0457-6

3. Green SM, Mostaghel EA, Nelson PS. Androgen action and metabolism in prostate cancer. Mol Cell Endocrinol 2012; 360:3-13. https://doi.org/10.1016/j.mce.2011.09.046

4. Friedlander TW, Roy R, Tomlins SA, Ngo VT, Kobayashi Y, Azameera A, et al. Common structural and epigenetic changes in the genome of castrationresistant prostate cancer. Cancer Res 2012; 72: 616-25.

https://doi.org/10.1158/0008-5472.CAN-11-2079

5. Cerqueira NM, Oliveira EF, Gesto DS, Santos-Martins D, Moreira $\mathrm{C}$, Moorthy $\mathrm{HN}$, et al. Cholesterol biosynthesis: a mechanistic overview. Biochem 2016; 55:5483-506. 
https://doi.org/10.1021/acs.biochem.6b00342

6. Miller WL. Androgen biosynthesis from cholesterol to DHEA. Mol Cell Endocrinol 2002; 198:7-14. https://doi.org/10.1016/S0303-7207(02)00363-5

7. Salvi S, Casadio V, Conteduca V, Burgio SL, Menna C, Bianchi E, et al. Circulating cell-free AR and CYP17A1 copy number variations may associate with outcome of metastatic castrationresistant prostate cancer patients treated with abiraterone. Br J Cancer 2015; 112:1717. https://doi.org/10.1038/bjc.2015.128

8. Santen RJ, Petroni GR, Fisch MJ, Myers CE, Theodorescu D, Cohen RB. Use of the aromatase inhibitor anastrozole in the treatment of patients with advanced prostate carcinoma. Cancer. 2001;
92:2095-2101.

https://doi.org/10.1002/1097$0142(20011015) 92: 8<2095$ ::AIDCNCR1550॰3.0.CO;2-Y

9. Sternberg CN. Drug management of prostate cancer. BJU Int 2011; 107:1509. https://doi.org/10.1111/j.1464410X.2011.10301.x

10. Wu G, Huang S, Nastiuk KL, Li, J, Gu J, $\mathrm{Wu} \mathrm{M}$, et al. Variant allele of HSD3B1 increases progression to castrationresistant prostate cancer. Prostate. 2003; 75(7):L777-82. http://doi.org/10.1002/pros.22967

11. Ji Q, Chang L, van Den Berg D, Stanczyk FZ, Stolz A. Selective reduction of AKR1C2 in prostate cancer and its role in DHT metabolism. Prostate 2003; 54:275-289.

https://doi.org/10.1002/pros.10192 